\title{
PENYELENGGARAAN PELAYANAN PUBLIK BERDASARKAN UNDANG-UNDANG TENTANG PELAYANAN PUBLIK DI KECAMATAN MEMPURA KABUPATEN SIAK
}

\author{
Ardiansah $^{* 1}$, Andrizal ${ }^{2}$ \\ 1, 2 Program Studi Ilmu Hukum, Fakultas Hukum, Universitas Lancang Kuning \\ *E-mail: ardiansah@unilak.ac.id
}

\begin{abstract}
This community service activity was carried out by the Lecturer Team of the Faculty of Law at Lancang Kuning University in the Hall of the District Office of Mempura District, Siak Regency. The purpose of this activity is for public service providers to understand their rights and obligations under the Public Service Act. This legal education uses the lecture method. Counseling that began filling out the pre-test questionnaire and after the question and answer ended the filling of the post-test questionnaire. The results of this activity showed that participants understood the Law on Public Services, understood the obligation to serve every citizen to fulfill their basic rights and needs, and understood the rights of the community to be involved in overseeing public service delivery. Therefore, the Regional Government needs to intensify the implementation of legal counseling about public services.
\end{abstract}

Keywords - Layanan Masyarakat, Undang-undang, Kabupaten Siak

\begin{abstract}
Abstrak
Kegiatan pengabdian kepada masyarakat ini dilakukan oleh Tim Dosen Fakultas Hukum Universitas Lancang Kuning di Aula Kantor Camat Kecamatan Mempura Kabupaten Siak. Tujuan kegiatan ini agar penyelenggara pelayanan publik memahami tentang hak dan kewajibannya berdasarkan Undang-Undang Pelayanan Publik. Penyuluhan hukum ini menggunakan metode ceramah. Penyuluhan diawali pengisian kuisioner pre test dan setelah tanya jawab diakhiri pengisian kuisioner post test. Hasil kegiatan ini menunjukkan bahwa peserta memahami tentang UndangUndang tentang Pelayanan Publik, memahami kewajiban melayani setiap warga negara untuk memenuhi hak dan kebutuhan dasarnya, dan memahami hak masyarakat untuk terlibat dalam pengawasan penyelengaaraan pelayanan publik. Oleh karena itu, Pemerintah Daerah perlu mengintensifkan pelaksanaan penyuluhan hukum mengenai pelayanan publik.
\end{abstract}

Kata Kunci - Public Services, Law, Siak Regency

\section{PENDAHULUAN}

Pelayanan Publik adalah suatu tindakan pemberian barang dan jasa kepada masyarakat oleh pemerintah dalam rangka tanggung jawabnya kepada publik, baik diberikan secara langsung maupun melalui kemitraan dengan swasta dan masyarakat, berdasarkan jenis dan intensitas kebutuhan masyarakat, kemampuan masyarakat dipasar. Konsep ini lebih menekankan bagaimana pelayanan publik berhasil diberikan melalui suatu delivery[1].

Pelayanan publik atau pelayanan umum dapat didefinisikan sebagai segala bentuk jasa pelayanan, baik dalam bentuk barang publik maupun jasa publik yang pada prinsipnya menjadi tanggung jawab dan dilaksanakan oleh instansi pemerintah di pusat, di daerah, dan di lingkungan Badan Usaha Milik Negara atau Badan Usaha Milik Daerah, dalam rangka upaya pemenuhan kebutuhan masyarakat maupun dalam rangka pelaksanaan ketentuan peraturan perundangundangan[2].

Dalam pandangan Agung Kurniawan, Pelayanan publik adalah pemberian pelayanan (melayani) keperluan orang lain atau masyarakat yang mempunyai kepentingan pada organisasi itu sesuai dengan aturan pokok dan tata cara yang telah di tetapkan[3]. Sementara menurut Undang- 
Undang Nomor 25 Tahun 2009 tentang Pelayanan Publik bahwa pelayanan publik sebagai kegiatan atau rangkaian kegiatan dalam rangka pemenuhan kebutuhan pelayanan sesuai dengan peraturan perundang- undangan bagi setiap warga negara dan penduduk atas barang, jasa, dan/atau pelayanan administratif yang disediakan oleh penyelenggara pelayanan publik.

Mencermati definisi tersebut, maka pelayanan publik berkaitan erat dengan kepentingan publik. Masyarakat berharap agar penyelenggara pelayanan publik bisa melayani penuh kejujuran, pengelolaan anggaran dengan tepat, dan bnisa dipertanggungjawabkan kepada publik. Terdapat empat elemen penting proses pelayanan publik. Pertama, Penyedia layanan, yaitu pihak yang dapat memberikan suatu layanan tertentu kepada konsumen, baik berupa laynaan dalam bentuk penyediaan dan penyerahan barang atau jasa. Kedua, Penerima layanan, yaitu mereka yang disebut sebagai konsumen atau pelanggan yang menerima berbagai layanan dari penyedia layanan. Ketiga, Jenis layanan, yaitu layanan yang dapat diberikan oleh penyedia layanan kepada pihak yang membutuhkan layanan. Keempat, Kepuasan pelanggan, dalam memberikan layanan penyedia layanan harus mengacu pada tujuan utama pelayanan, yaitu kepuasan pelanggan. Hal ini sangat penting dilakukan karena tingkat kepuasan yang diperoleh para pelanggan itu biasanya sangat berkaitan erat dengan standar kualitas barang atau jasa yang mereka nikmati[4].

Pelayanan publik diibaratkan sebagai sebuah proses, dimana ada orang yang dilayani, melayani, dan jenis dari pelayanan yang diberikan. Sehingga kiranya pelayanan publik memuat hal-hal yang subtansial yang berbeda dengan pelayanan yang diberikan oleh swasta. Pelayanan publik adalah pelayanan yang diberikan oleh pemerintah dalam rangka memenuhi segala kebutuhan masyarakat, sehingga dapat dibedakan dengan pelayanan yang dilakukan oleh swasta[5].

Dalam kondisi perkembangan masyarakat yang dinamis, birokrasi publik harus dapat memberikan pelayanan publik yang lebih profesional, efektif, sederhana, transparan, terbuka, tepat waktu, responsif dan adaptif serta sekaligus dapat membangun kualitas manusia dalam arti meningkatkan kapasitas individu dan masyarakat untuk secara aktif menentukan masa depannya sendiri. Arah pembangunan kualitas manusia tadi adalah memberdayakan kapasitas manusia dalam arti menciptakan kondisi yang memungkinkan setiap anggota masyarakat mengembangkan kemampuan dan krativitasnya untuk mengatur dan menentukan masa depannya sendiri[6].

Untuk membangun sistem pelayanan publik yang berpihak pada rakyat, harus didorong perubahan budaya birokrasi, dari budaya kekuasaan menuju budaya pelayanan. Untuk itu, praktik dan kebiasaan dalam penyelenggaraan pelayanan yang selama ini sering melecehkan martabat pengguna jasa harus digusur dengan sikap ramah dan helpful. Nilai dan simbol dalam kehidupan birokrasi yang mengidentikkan birokrasi dengan kekuasaan harus diganti dengan nilai dan simbol pelayanan. Redefinisi misi dan visi birokrasi perlu dilakukan untuk menempatkan pengguna jasa sebagai sentral kehidupan birokrasi[7].

Pelayanan publik merupakan tanggungjawab pemerintah dan dilaksanakan oleh instansi pemerintah, baik itu di pusat, di daerah, dan dilingkungan Badan Usaha Milik Negara. Pelayanan publik kepada masyarakat adalah salah satu tugas atau fungsi penting pemerintah dalam menyelenggarakan tugas-tugas pemerintahannya. Pelayanan publik merupakan unsur yang sangat penting dalam penyelenggaraan pemerintahan karena menyangkut aspek kehidupan yang sangat luas. Penyelenggaraan pelayanan publik merupakan upaya Negara untuk memenuhi kebutuhan dasar dan hak-hak sipil setiap warga Negara atas barang, jasa, dan pelayanan administrasi yang disediakan oleh penyelenggara pelayanan publik. Karakteristik pelayanan publik yang sebagian besar bersifat monopoli membuat pemerintah tidak menghadapi pemasalahan persaingan pasar sehingga menyebabkan lemahnya perhatian pengelola pelayanan publik akan penyediaan pelayanan yang berkualitas. Lebih buruk lagi kondisi ini menjadikan sebagian pengelola pelayanan memanfaatkan untuk mengambil keuntungan pribadi, dan cenderung mempersulit prosedur [8].

Pelayanan publik menjadi tolok ukur keberhasilan pelaksanaan tugas dan pengukuran kinerja pemerintah melalui birokrasi. Pelayanan publik sebagai penggerak utama juga dianggap penting oleh semua aktor dari unsur good governance. Para pejabat publik, unsur-unsur dalam masyarakat sipil dan dunia usaha sama-sama memiliki kepentingan terhadap perbaikan kinerja pelayanan publik. Ada tiga alasan penting yang melatarbelakangi bahwa pembaharuan pelayanan publik dapat mendorong praktik good governance di Indonesia. Pertama, perbaikan kinerja pelayanan publik dinilai penting oleh stakeholders, yaitu pemerintah, warga, dan sektor usaha. 
Kedua. Pelayanan publik adalah ranah dari ketiga unsur governance melakukan interaksi yang sangat intensif. Ketiga, nilai-nilai yang selama ini mencirikan praktik good governance diterjemahkan secara lebih mudah dan nyata melalui pelayanan publik[9].

Pelayanan publik menjadi suatu tolok ukur kinerja pemerintah yang paling kasat mata. Dalam hal ini masyarakat dapat langsung menilai kinerja pemerintah berdasarkan kualitas layanan publik yang diterima, karena kualitas layanan publik menjadi kepentingan banyak orang dan dampaknya langsung dirasakan masyarakat dari semua kalangan[10].

Dalam menghadapi era globalisasi yang penuh tantangan dan peluang, aparatur Negara dalam hal ini dititikberatkan kepada aparatur pemerintahan hendaknya memberikan pelayanan yang sebaik-baiknya, berorientasi pada kebutuhan dan kepuasan penerima pelayanan, sehingga dapat meningkatkan daya saing dalam pemberi pelayanan barang dan jasa[11].

Dalam menghadapi era globalisasi yang penuh tantangan dan peluang, aparatur negara dalam hal ini dititikberatkan kepada aparatur pemerintah hendaknya memberikan pelayanan yang sebaik-baiknya, berorientasi pada kebutuhan dan kepuasan penerima pelayanan, sehingga dapat meningkatkan daya saing dalam pemberian pelayanan barang dan jasa[12].

Pelayanan publik menjadi sorotan kinerja pemerintah sejak lama. Hal ini ditandai dengan masih adanya berbagai keluhan masyarakat yang disampaikan melalui media massa, sehingga dapat menimbulkan citra yang kurang baik terhadap aparatur pemerintah. Mengingat fungsi utama pemerintah adalah melayani masyarakat, maka pemerintah perlu terus berupaya meningkatkan kualitas pelayanan. Pelayanan publik menjadi suatu tolok ukur kinerja pemerintah yang paling kasat mata. Masyarakat dapat langsung menilai kinerja pemerintah berdasarkan kualitas layanan publik yang diterima karena kualitas layanan publik menjadi kepentingan banyak orang dan dampaknya langsung dirasakan masyarakat dari semua kalangan, dimana keberhasilan dalam membangun kinerja pelayanan publik secara profesional, efektif, efisien dan akuntabel akan mengangkat citra positif pemerintah di mata warga masyarakatnya[13].

Pelayanan publik oleh aparatur pemerintah dewasa ini masih banyak dijumpai kelemahan sehingga belum dapat memenuhi kualitas yang diharapkan masyarakat. Hal ini ditandai dengan masih adanya berbagai keluhan masyarakat yang disampaikan melalui media massa, sehingga dapat menimbulkan citra yang kurang baik terhadap aparatur pemerintah. Mengingat fungsi utama pemerintah adalah melayani masyarakat maka pemerintah perlu terus berupaya meningkatkan kualitas pelayanan[14].

Dalam perjalanannya ternyata pelayanan publik menemui berbagai macam rintangan yang menghadang. Salah satunya adalah paradigma birokrasi yang cenderung untuk minta dilayani ketimbang melayani. Hal tersebut mengakibatkan berbagai persoalanseperti berbelit-belit, tidak efektif dan efisien, sulit dipahami, sulit dilaksanakan, tidak akurat, tidak transparan, tidak adil, birokratis, tidak profesional, tidak akuntabel, keterbatasan teknologi, keterbatasan informasi, kurangnya kepastian hukum, KKN, biaya tinggi, polarisasi politis, sentralistik, tidak adanya standar baku dan lemahnya kontrol masyarakat. Sedangkan telah terjadi pergeseran paradigma pelayanan publik dimana rakyat atau warga Negara adalah fokus dari pelayanan[15].

Fenomena pelayanan publik oleh birokrasi pemerintah sarat dengan permasalahan, misalnya prosedur pelayanan yang berteletele, ketidakpastian waktu dan harga yang menyebabkan pelayanan menjadi sulit dijangkau secara wajar oleh masyarakat. Hal ini menyebabkan terjadi ketidakpercayaan kepada pemberi pelayanan dalam hal ini birokrasi sehingga masyarakat mencari jalan alternatif untuk mendapatkan pelayanan melalui cara tertentu yaitu dengan memberikan biaya tambahan[9].

Pelayanan publik yang baik menjadi isu kebijakan yang strategis karena pelayanan publik sangat berimplikasi luas khususnya dalam memperbaiki kepercayaan kepada pemerintah. Suatu fenomena yang sekaligus menjadi masalah utama yaitu belum optimalnya kinerja aparatur pemda dalam menjalankan tugas dan fungsinya, yang ditunjukkan masih banyaknya keluhan-keluhan yang disampaikan masyarakat atas pelayanan yang diberikan pemda selama ini. Oleh karena itu perbaikan pelayanan publik mutlak diperlukan agar imageburuk masyarakat kepada pemerintah dapat diperbaiki, karena dengan perbaikan kualitas pelayanan publik dapat mempengaruhi kepuasan masyarakat sehingga kepercayaan masyarakat terhadap pemerintah dapat dibangun kembali[16].

Pemerintah mempunyai peranan penting untuk menyediakan layanan publik yang prima 
bagi semua penduduknya sesuai yang telah diamanatkan dalam Undang-Undang Nomor 25 Tahun 2009 tentang pelayanan publik[17].

Indonesia sejak tahun 2009 telah memiliki peraturan perundangan tersendiri sebagai sebuah standar bagi pelayanan kepada masyarakat, maka pada tanggal 18 Juli 2009 Indonesia mensahkan Undang-Undang No 25 tahun 2009 tentang Pelayanan Publik. Menurut undang-undang tersebut, Pelayanan publik adalah kegiatan atau rangkaian kegiatan dalam rangka pemenuhan kebutuhan pelayanan sesuai dengan peraturan perundangan bagi setiap warga negara dan penduduk atas barang, jasa, dan/atau pelayanan administratif yang disediakan oleh penyelenggara pelayanan publik[18].

Mencermati hal tersebut, maka perlu dilaksanakan penyuluhan hukum terhadap penyelenggara pelayanan publik dan masyarakat. Dengan adanya penyuluhan hukum ini, maka laksana pelayanan publik dan masyarakat dapat memahami hak dan kewajibannya dalam pelayanan publik. Selain itu, penyelengga pelayanan publik dan masyarakat dapat memahami aspek hukum pelayanan publik, sehingga mereka dapat berinteraksi dengan baik dalam bidang pelayanan publik.

\section{METODE}

Pelaksanaan pengabdian kepada masyarakat ini menggunakan metode penyuluhan hukum. Perincian metode kegiatan sebagai berikut: (1) Ceramah. Salah seorang tim penyuluh memaparkan tentang penyelenggaraan pelayanan publik berdasarkan Undang-Undang Nomor 25 Tahun 2009 tentang Pelayanan Publik. (2) Dialog interaktif. Peserta penyuluhan berposisi sebagai subjek yang bisa memberikan pertanyaan mengenai berbagai permasalahan yang berkaitan dengan penyelenggaraan pelayanan publik. Dialog interaktif ini merupakan curah pendapat dari penyuluh dan peserta yang berisi persoalan, usulan, ide, aspirasi, dan solusi. (3) Kuisioner. Kuisioner disebarkan sebelum dan sesudah dilaksanakannya ceramah dalam bentuk pre test dan post test. Penyebaran kuisioner bertujuan untuk mengukur tingkat pemahaman peserta sebagai aparatur kecamatan dan aparatur desa Kecamatan Mempura Kabupaten Siak berdasarkan Undang-Undang Nomor 25 Tahun 2009 tentang Pelayanan Publik.

\section{HASIL DAN PEMBAHASAN}

Berdasarkan hasil kegiatan penyuluhan hukum tentang penyelenggaraan pelayanan publik berdasarkan Undang-Undang Nomor 25 Tahun 2009 tentang Pelayanan Publik di Kecamatan Mempura Kabupaten Siak memperlihatkan gambaran bahwa pemahaman abdi negara meningkat sesuai dengan tujuan target yang diharapkan. Hal ini dapat dibuktikan dengan berbagai pertanyaan peserta dan hasil jawaban isian kuisioner pre test dan post test mengenai pelayanan publik berdasarkan Undang-Undang Nomor 25 Tahun 2009 tentang Pelayanan Publik.

Kegiatan pengabdian kepada masyarakat bidang kajian ipteks hukum ini menitikberatkan pada permasalahan berkaitan dengan hak dan kewajiban penyelenggara pelayanan publik dan anggota masyarakat di Kecamatan Mempura Kabupaten Siak mengenai pelayanan publik. Agar kegiatan penyuluhan hukum ini bermanfaat bagi peserta, maka panitia memberikan panduan kepada peserta dalam bentuk slide yang telah difotocopi. Panduan dalam bentuk slide ini berisi hak dan kewajiban masyarakat Kecamatan Mempura Kabupaten Siak mengenai pelayanan publik. Tujuannya agar tercapainya pemahaman penyelenggara pelayanan publik dan anggota masyarakat tentang hak dan kewajiban masyarakat Kecamatan Mempura Kabupaten Siak mengenai pelayanan publik, sehingga ke depan masyarakat memperoleh pelayanan publik yang sesuai dengan ketentuan hukum yang berlaku. 


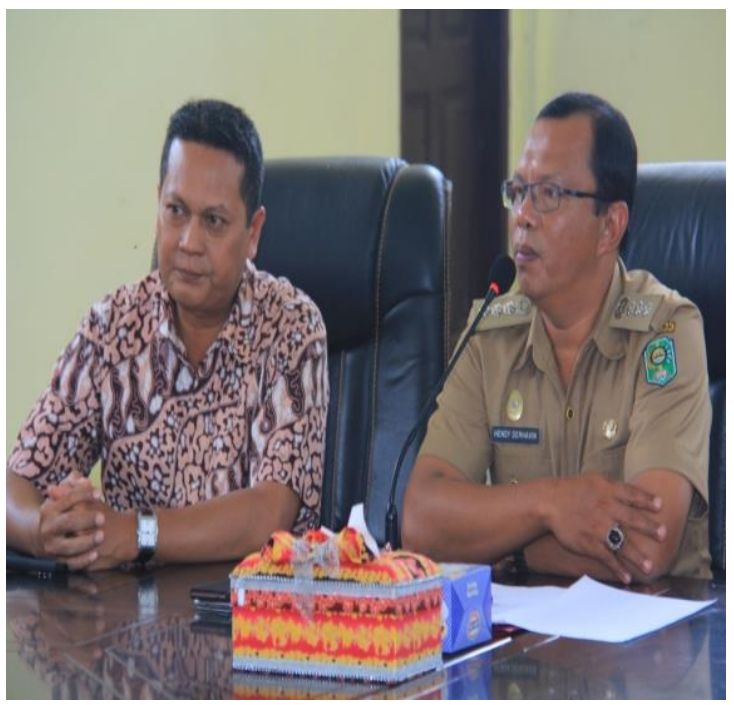

Gambar: Kata Sambutan Camat Mempura Kabupaten Siak Bapak Hendy Derhavin

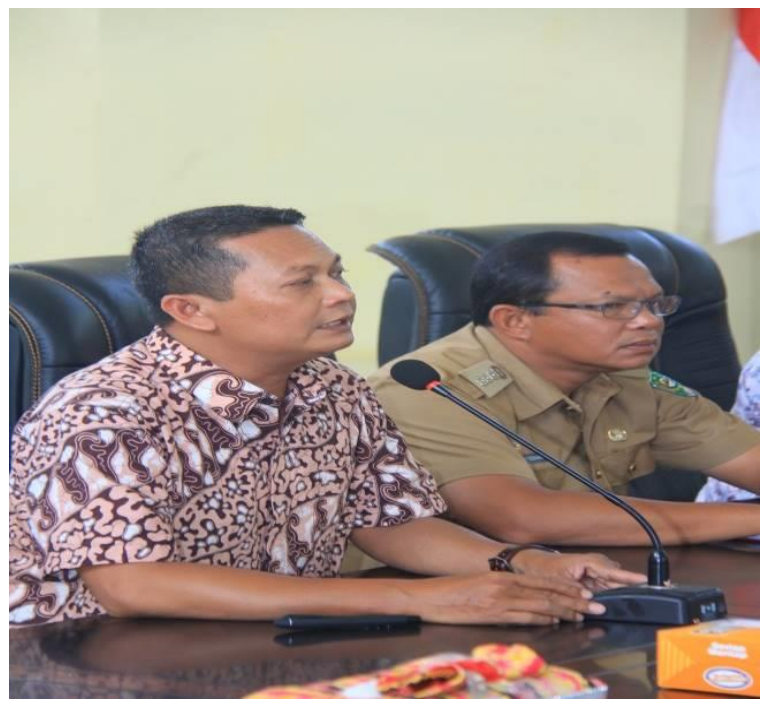

Gambar: Kata Sambutan Ketua Tim Pengabdian kepada Masyaralat Bapak Ardiansah

Kegiatan ini dilaksanakan pada hari Rabu, 4 Maret 2015, bertempat di Aula kantor Camat Kecamatan Mempura Kabupaten Siak, mulai Pukul 9.00 WIB hingga 12.00 WIB. Jumlah peserta yang hadir sebanyak 24 orang. Kegiatan ini dihadiri oleh Camat Kecamatan Mempura Kabupaten Siak, Bapak Hendy Derhavin, S.E., M.M., Tim Pengabdian kepada Masyarakat Universitas Lancang Kuning Bapak Dr. Ardiansah, S.H., M.Ag., M.H (Ketua) dan Andrizal, SH., MH (Anggota), 4 (empat) orang mahasiswa Fakultas Hukum Universitas Lancang Kuning yang dilibatkan dalam penyuluhan hukum, dan aparatur kecamatan/aparatur desa sebagai peserta penyuluhan hukum.

Dalam kegiatan penyuluhan hukum ini, Dr. Ardiansah, S.H., M.Ag., M.H., memberikan kata sambutan sekaligus menyampaikan materi penyuluhan hukum. Ardiansah mengucapkan terima kasih kepada Camat Kecamatan Mempura Kabupaten Siak yang telah berkenan bekerjasama mengadakan kegiatan ini. Penyuluhan hukum ini merupakan kegiatan sharing ilmu pengetahuan hukum. Tim penyuluhan hukum yang menguasai ilmu hukum memberikan pengetahuan hukum kepada aparatur kecamatan dan aparatur desa yang berkaitan dengan Penyelenggaraan Pelayanan Publik berdasarkan Undang-Undang Nomor 25 Tahun 2009 tentang Pelayanan Publik. Selain itu, adanya penyuluhan hukum ini bisa menambah wawasan bagi aparatur kecamatan dan aparatur desa selaku penyelenggara pelayanan publik dalam pemenuhan hak dan kewajibannya sebagai penyelenggara pelayanan publik berdasarkan Undang-Undang Nomor 25 Tahun 2009 tentang Pelayanan Publik.

Camat Kecamatan Mempura Kabupaten Siak, Bapak Hendy Derhavin, S.E., M.M., menyambut baik dilaksanakannya penyuluhan hukum mengenai topik Penyelenggaraan Pelayanan Publik Kecamatan Mempura Kabupaten Siak Berdasarkan Undang-Undang Nomor 25 Tahun 2009 tentang Pelayanan Publik. Hendy Derhavin mengucapkan terima kasih kepada Tim Pengabdian kepada Masyarakat yang telah berkenan hadir dan memberikan penyuluhan hukum kepada aparatur kecamatan dan aparatur desa mengenai topik Penyelenggaraan Pelayanan Publik berdasarkan Undang-Undang Nomor 25 Tahun 2009 tentang Pelayanan Publik di Kecamatan Mempura Kabupaten Siak. Hendy Derhavin mengapresiasi kegiatan ini dan mengusulkan agar pada masa datang kegiatan seperti ini bisa dilaksanakan secara berkelanjutan. 


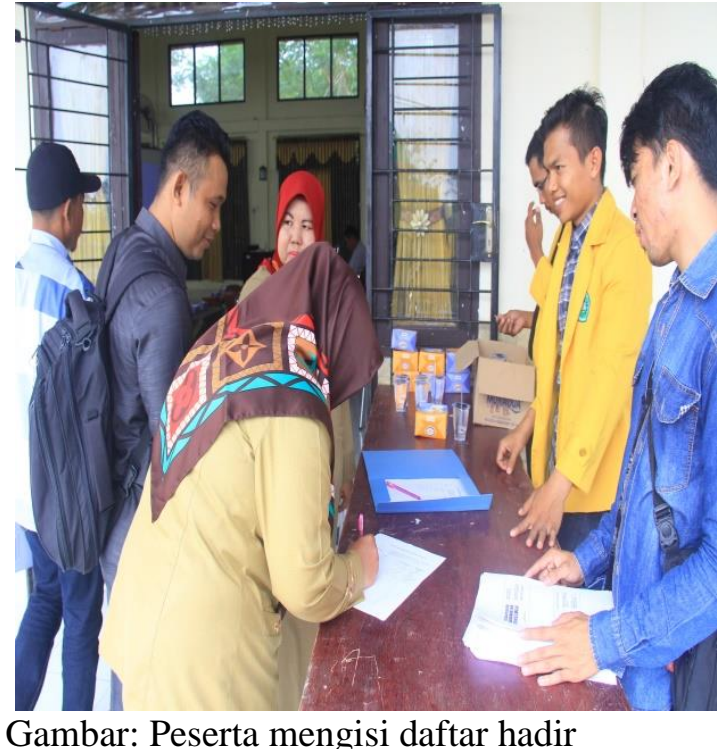

Gambar: Peserta mengisi daftar hadir

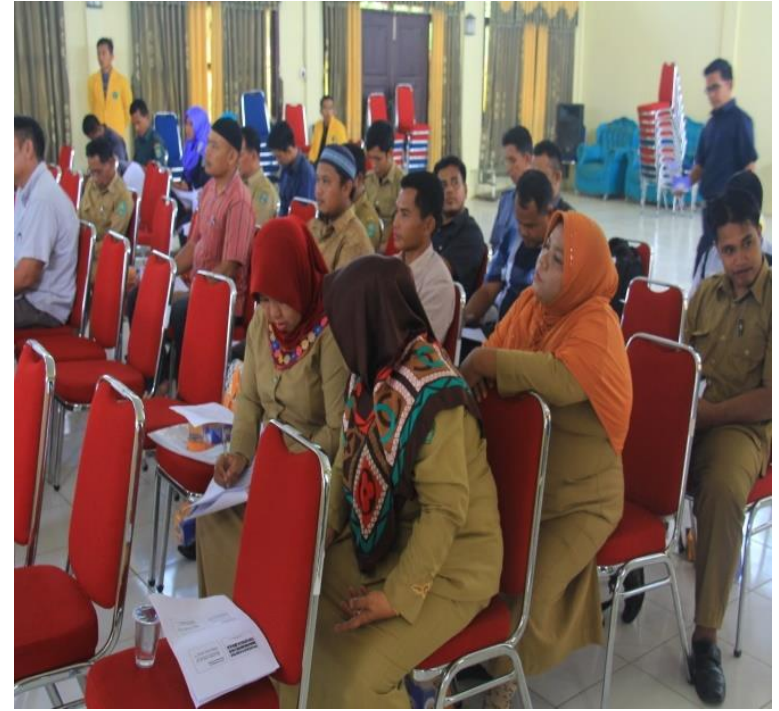

Gambar: peserta menyimak materi penyuluhan

Sebelum Tim Pengabdian kepada Masyarakat menyampaikan materi peyuluhan hukum terlebih dahulu sebarkan kuisioner pre test dan peserta diminta mengisi kuisioner dan dikumpulkan sebelum penyampaian materi. Setelah penyampaian materi, Tim Pengabdian kepada Masyarakat kembali sebarkan kuisioner post test dan peserta diminta mengisi kuisioner. Tujuan pengisian kuisioner untuk mengukut tingkat pemahaman peserta terhadap materi penyuluhan hukum. Dari pengisian kuisioner diperoleh hasil bahwa meningkat pemahaman peserta terhadap materi penyluhan hukum.

Peningkatan pemahaman peserta bisa terlihat dari hasil pre test dan pos test. Tahapan evaluasi kegiatan penyuluhan hukum ini dilakukan dengan cara menyebarkan kuisioner berupa pertanyaan yang harus dijawab oleh peserta yang berjumlah 24 orang seputar pertanyaan tentang Penyelenggaraan Pelayanan Publik Berdasarkan Undang-Undang Nomor 25 Tahun 2009 tentang Pelayanan Publik Di Kecamatan Mempura Kabupaten Siak. Kuisioner diberikan kepada peserta sebanyak dua lembar, berupa kuisiner awal kehadiran dan kuisiner akhir kehadiran. Kuisioner awal kehadiran diberikan kepada peserta sebelum pemateri memberikan ceramah, sedangkan kuisioner akhir kehadiran diberikan kepada peserta setelah pemateri selesai memberikan ceramah. Sebaran kuisioner ini dilakukan bertujuan untuk mengukur tingkat pengetahuan dan pemahaman peserta mengenai Undang-Undang Nomor 25 Tahun 2009 tentang Pelayanan Publik.

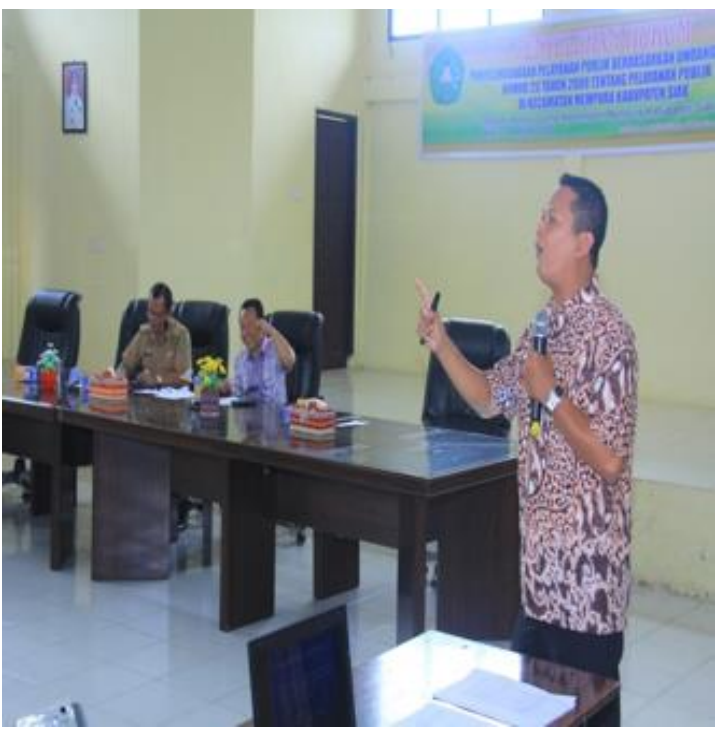

Gambar: Bapak Ardiansah menyampaikan materi penyuluhan hukum, sementara peserta menyimak materi penyuluhan hukum

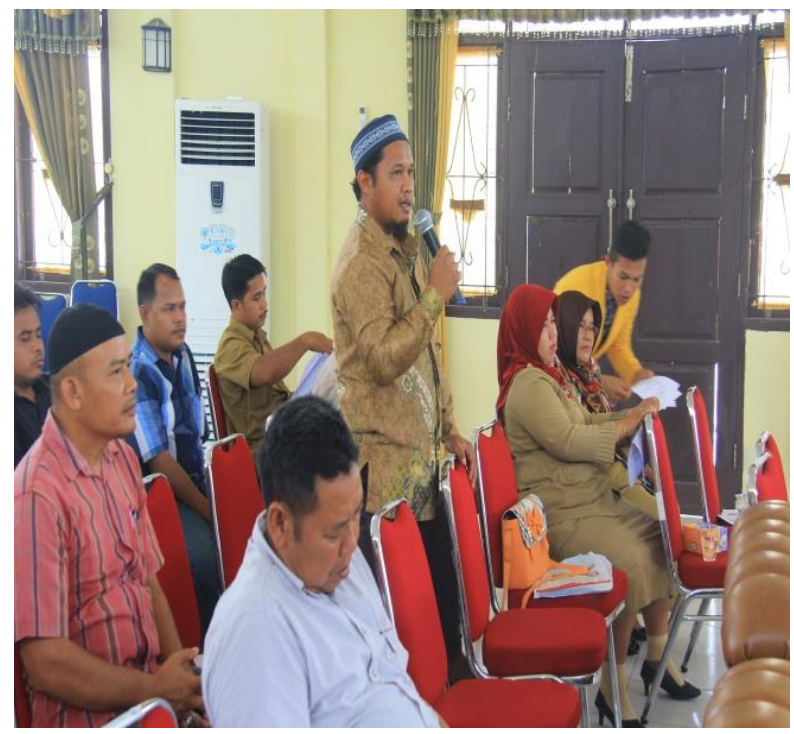

Gambar: Salah satu peserta mengajukan pertanyaan 
Peningkatan pemahaman peserta terlihat dari jawaban peserta yang mengisi kuisioner akhir kehadiran. Sebagian besar peserta memilih jawaban yang benar. Gambaran mengenai bentuk pertanyaan dan jawaban yang dipilih peserta dapat dilihat dari jawaban di bawah ini.

1. Negara berkewajiban melayani setiap warga negara untuk:

a. Memenuhi hak dan kebutuhan hidupnya

b. Memenuhi hak dan kebutuhan dasarnya

c. Memenuhi hak dan kebutuhan keluarganya

Dari 24 orang peserta yang menjawab pertanyaan tersebut, dapat diketahui peserta yang memilih jawaban yang benar (b), sebanyak 23 orang. Peserta yang memilih jawaban yang salah (a), sebanyak 1 orang. Sedangkan peserta yang memilih jawaban yang salah (c), tidak ada. Jawaban tersebut menunjukkan bahwa sebagian besar peserta yang hadir memilih jawaban yang benar, (b). Berdasarkan hasil jawaban tersebut menunjukkan bahwa sebagian besar peserta telah memahami mengenai negara berkewajiban melayani setiap warga negara untuk memenuhi hak dan kebutuhan dasarnya.

2. Undang-Undang Nomor 25 Tahun 2009 tentang Pelayanan Publik diperlukan untuk :

a. Meningkatkan kewenangan penyelenggara pelayanan publik

b. Memberi perlindungan bagi individu tertentu

c. Menjamin penyediaan pelayanan publik

Dari 24 orang peserta yang menjawab pertanyaan tersebut, dapat diketahui peserta yang telah memilih jawaban yang benar (c), sebanyak 13 orang. Peserta yang memilih jawaban yang salah (a), sebanyak 11 orang. Sedangkan peserta yang memilih jawaban yang salah (b), tidak ada. Jawaban tersebut menunjukkan bahwa lebih setengah peserta yang hadir memilih jawaban yang benar, (c). Berdasarkan hasil jawaban tersebut menunjukkan bahwa banyak peserta telah memahami Undang-Undang Nomor 25 Tahun 2009 tentang Pelayanan Publik diperlukan untuk menjamin penyediaan pelayanan publik.

3. Pelayanan publik penting bagi masyarakat karena :

a. Semua urusan berkaitan dengan pelayanan publkc

b. Memperkuat sistem pertahanan dan keamanan Indonesia

c. Menegakkan hak asasi manusia, seperti politik, pemerintahan, ekonomi, dan lain-lain.

Dari 24 orang peserta yang menjawab pertanyaan tersebut, dapat diketahui peserta yang telah memilih jawaban yang benar, (c), sebanyak 19 orang. Peserta yang memilih jawaban yang salah (a), sebanyak 5 orang. Sedangkan peserta yang memilih jawaban yang salah (b), tidak ada. Jawaban tersebut menunjukkan bahwa sebagian besar peserta yang hadir memilih jawaban yang benar, (c).Berdasarkan dari jawaban tersebut menunjukkan bahwa sebagian besar peserta telah memahami pelayanan publik penting bagi masyarakat karena menegakkan hak asasi manusia, seperti politik, pemerintahan, ekonomi, dan lain-lain.

4. Dalam ragka penyelenggaraan pelayanan publik, masyarakat diberi hak untuk:

a. Terlibat dalam pengawasan penyelenggaraan pelayanan publik

b. Terlibat dalam penyelenggaraan pelayanan publik

c. Terlibat dalam penyusunan laporan kinerja pelayanan publik

Dari 24 orang peserta yang menjawab pertanyaan tersebut, dapat diketahui peserta yang telah memilih jawaban yang benar (a), sebanyak 20 orang. Peserta yang memilih jawaban yang salah (b), sebanyak 2 orang. Sedangkan peserta yang memilih jawaban yang salah (c), sebanyak 2 orang. Jawaban tersebut menunjukkan bahwa sebagian besar peserta yang hadir memilih jawaban yang benar, (a). Berdasarkan hasil jawaban tersebut menunjukkan bahwa sebagian besar peserta telah memahami dalam rangka penyelenggaraan pelayanan publik, maka masyarakat diberikan hak untuk terlibat dalam pengawasan penyelenggaraan pelayanan publik.

5. Pasal 34 Undang-Undang Nomor 25 Tahun 2009menyebutkan pelaksana dalam menyelenggarakan pelayanan publik harus berperilaku :

a. Tegas dan tidak memberikan putusan yang berlarut-larut

b. Jenaka dan Ceria

c. Lembut dan Sopan

Dari 24 orang peserta yang menjawab pertanyaan tersebut, dapat diketahui peserta yang telah memilih jawaban yang benar (a), sebanyak 22 orang. Peserta yang memilih jawaban yang salah (b), tidak ada. Sedangkan peserta yang memilih jawaban yang salah (c), sebanyak 2 orang. 
Jawaban tersebut menunjukkan bahwa sebagian besar peserta yang hadir memilih jawaban yang benar, (a). Berdasarkan hasil jawaban tersebut menunjukkan bahwa sebagian besar peserta telah memahami Pasal 34 Undang-Undang Nomor 25 Tahun 2009 menyebutkan pelaksana dalam menyelenggarakan pelayanan publik harus berperilaku tegas dan tidak memberikan putusan yang berlarut-larut.

6. Penyelenggara pelayanan publik yang menyalahgunakan wewenang atau melakukan perbuatan melawan hukum dapat dikenakan sanksi berupa:
a. Teguran Lisan
b. Pembebasan Tugas
c. Pemberhentian Dengan Hormat

Dari 24 orang peserta yang menjawab pertanyaan tersebut, dapat diketahui peserta yang telah memilih jawaban yang benar (c), sebanyak 16 orang. Peserta yang memilih jawaban yang salah (a), sebanyak 6 orang. Sedangkan peserta yang memilih jawaban yang salah (b), sebanyak 2 orang. Jawaban tersebut menunjukkan bahwa sebagian besar peserta yang hadir memilih jawaban yang benar, (c). Berdasarkan hasil jawaban tersebut menunjukkan bahwa sebagian besar peserta telah memahami penyelenggara pelayanan publik yang menyalahgunakan wewenang atau melakukan perbuatan melawan hukum dapat dikenakan sanksi berupa pemberhentian dengan hormat.

Berdasarkan dari evaluasi melalui sebaran kuisioner dan jawaban peserta tersebut menunjukkan bahwa sebagian besar peserta penyuluhan hukum memahami materi mengenai Penyelenggaraan Pelayanan Publik berdasarkan Undang-Undang Pelayanan Publik di Kecamatan Mempura Kabupaten Siak. Hal ini dapat dilihat dari tanggapan peserta yang sebagian besar memilih jawaban yang benar. Pertama, peserta memahami negara berkewajiban melayani setiap warga negara untuk memenuhi hak dan kebutuhan dasarnya. Kedua, peserta memahami UndangUndang Nomor 25 Tahun 2009 tentang Pelayanan Publik diperlukan untuk menjamin penyediaan pelayanan public. Ketiga, peserta memahami pelayanan publik penting bagi masyarakat karena pelayanan publik penting bagi masyarakat karena menegakkan hak asasi manusia, seperti politik. Keempat, peserta memahami pemerintahan, ekonomi, dan lain-lain, dalam rangka penyelenggaraan pelayanan publik, masyarakat diberi hak untuk terlibat dalam pengawasan penyelengaaraan pelayanan publik. Kelima, Pasal 34 Undang-Undang Nomor 25 Tahun 2009 menyebutkan pelaksana dalam menyelenggarakan pelayanan publik harus berperilaku tegas dan tidak memberikan putusan yang berlarut-larut. Keenam, peserta memahami penyelenggara pelayanan publik yang menyalahgunakan wewenang atau melakukan perbuatan melawan hukum dapat dikenakan sanksi berupa pemberhentian dengan hormat.
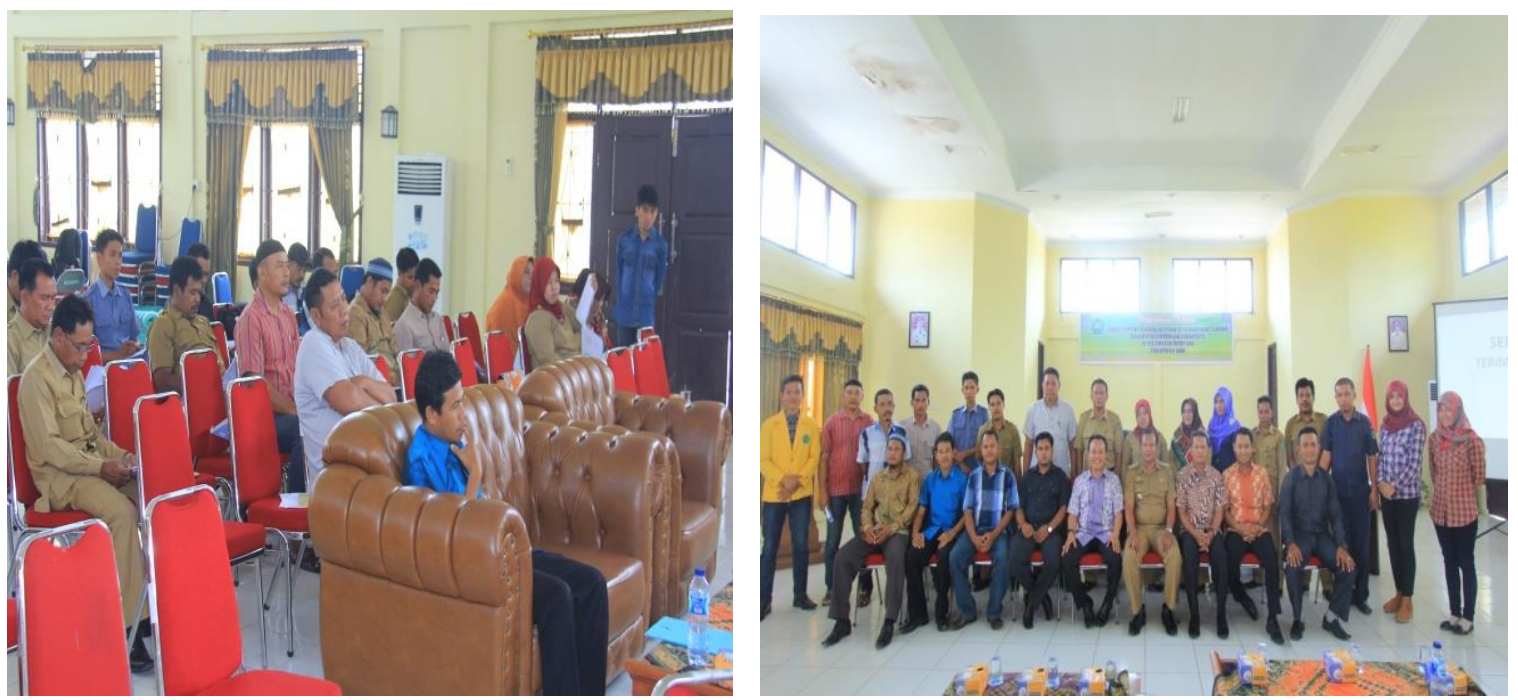

Gambar bersama Tim Pengabdian kepada Masyarakat dan peserta penyuluhan hukum 


\section{KESIMPULAN}

Setelah dilaksanakannya penyuluhan hukum yang tetapkan sebagai metode kegiatan pengabdian kepada masyarakat, maka bisa disimpulkan peserta memahami bahwa Undang-Undang Nomor 25 Tahun 2009 tentang Pelayanan Publik sangat diperlukan untuk menjamin terselenggaranya pelayanan publik bagi masyarakat, peserta memahami bahwa pemerintah Indonesia mempunyai kewajiban dan tanggung jawab untuk melayani setiap warga negara Indonesia dalam rangka memenuhi hak-hak dan kebutuhan dasarnya, dan peserta memahami bahwa masyarakat mempunyai hak untuk terlibat aktif dalam pengawasan terhadap penyelengaraan pelayanan publik.

\section{SARAN}

Berdasarkan seluruh rangkaian kegiatan pengabdian kepada masyarakat tersebut terdapat beberapa saran. Pertama, Pemerintah Daerah Kabupaten Siak perlu lebih intensif menyelenggarakan kegiatan penyuluhan hukum bertema pelayanan publik agar meningkatkan pemahaman dan kemampuan aparatur kecamatan dan aparatur desa dalam penyelenggaraan pelayanan publik. Kedua, Pemerintah Provinsi Riau perlu mengintensifkan pelaksanaan penyuluhan hukum mengenai Undang-Undang Nomor 25 Tahun 2009 tentang Pelayanan Publik ke seluruh kecamatan di Provinsi Riau.

\section{UCAPAN TERIMAKASIH}

Penulis mengucapkan terima kasih kepada Rektor Universitas Lancang Kuning, Ketua Lembaga Penelitian dan Pengabdian Masyarakat Universitas Lancang Kuning, Camat Kecamatan Mempura Kabupaten Siak, Aparatur Kecamatan Mempura Kabupaten Siak, dan Aparatur Desa SeKecamatan Mempura Kabupaten Siak serta seluruh pihak yang telah ikut serta terlibat dalam terselenggaranya kegiatan pengabdian kepada masyarakat ini.

\section{DAFTAR PUSTAKA}

[1] A. M. Saleh, Public Service Comnunication (praktik komunikasi dalam Pelayanan Publik). Malang: UMM Press, 2010.

[2] H. Wibawa, "Pengawasan Ombudsman Terhadap Penyelenggara Negara Dan Pemerintahan (Studi Perbandingan Dengan Pengawasan Peratun)," Universitas Diponegoro, 2010.

[3] A. Kurniawan, Transformasi Pelayanan Publik. Yogyakarta, 2005.

[4] A. Brata, Dasar-Dasar Pelayanan Prima. Jakarta: Elex Media Komputindo, 2004.

[5] Ratminto, Manajemen Pelayanan. Yogyakarta: Pustaka Pelajar, 2006.

[6] A. Sukardi, Participatory Governance dalam Pengelolaan Keuangan Daerah. Yogyakarta: Laksbang Presindo.

[7] A. Dwiyanto, "Membangun Sistem Pelayanan Publik yang Memihak pada Rakyat," J. Popul., vol. 12 , no. 1, p. 16, 2002.

[8] M. H. Pratama, "Strategi Meningkatkan Kualitas Pelayanan Publik (Studi Deskriptif Tentang Strategi Uptd Pengujian Kendaraan Bermotor Tandes Kota Surabaya Dalam Meningkatkan Kualitas Pelayanan Pengujian Kendaraan Bermotor)," J. Kebijak. dan Manaj. Publik, vol. 3, no. 3, p. 90, 2015.

[9] N. S. Maryam, "Mewujudkan Good Governance Melalui Pelayanan Publik," J. Ilmu Polit. dan Komun., vol. 6, no. 1, p. 2, 2016.

[10] B. Munir, Perencanaan Daerah dalam Perspektif Otoda. Mataram: Bappeda Mataram, 2002.

[11] N. Kamarni, "Analisis Pelayanan Publik Terhadap Masyarakat (Kasus Pelayanan Kesehatan Di Kabupaten Agam)," J. Manaj. dan Kewirausahaan, vol. 2, no. 3, p. 84, 2011.

[12] Surjadi, Pengembangan Kinerja Pelayanan Publik. Bandung: Refika Aditama, 2009.

[13] Sutopo, "Pentingnya Tata Informasi Tentang Pelayanan Publik Bagi Masyarakat, Journal of Rural and Development," J. Rural Dev., vol. V, no. 1, pp. 15-16, 2014.

[14] R. Rinaldi, "Analisis Kualitas Pelayanan Publik (Studi Pada Biro Umum Sekretariat Daerah 
Propinsi Sumatera Utara," J. Adm. Publik, vol. 1, no. 1, 2012.

[15] A. A. Wakhid, "Reformasi Pelayanan Publik Di Indonesia," J. Teropong Aspir. Polit. Islam, vol. 1, no. 14, p. 54, 2017.

[16] L. B. E. M. Purwaningdyah, "Meningkatkan Kompetensi Aparatur Pemerintah Daerah Dalam MewujudkanGood Governance," J. Kebijak. dan Manaj. PNS, vol. 2, 2008.

[17] Y. Rukayat, "Kualitas Pelayanan Publik Bidang Administrasi Kependudukan Di Kecamatan Pasirjambu," J. Ilm. Magister Ilmu Adm., p. 56, 2017.

[18] R. C. Kurniawan, "Inovasi Kualitas Pelayanan Publik Pemerintah Daerah," Fiat Justisia J. Law, vol. 10, no. 3, pp. 570-571, 2016. 